\title{
PERSONALIZED APPROACH TO THE TREATMENT OF SUPPORTING MOTOR DISTURBANCES OF THE LOWER EXTREMITIES IN CHILDREN WITH SPASTIC FORMS OF CEREBRAL PALSY
}

Fisenko A. P., Chelpachenko O. B., Pak L. A., Volkova M. O., Zubkov P. A., Zherdev K. V., Ashrafova U. Sh., Kirgizov I. V.

National Medical Research Center of Children's Health, Moscow, Russian Federation

\section{ПЕРСОНИФИЦИРОВАННЫЙ ПОАХОА К АЕЧЕНИЮ ОПОРНО-АВИГАТЕАЬНЫХ НАРУШЕНИЙ НИЖНИХ КОНЕЧНОСТЕЙ ПРИ СПАСТИЧЕСКИХ ФОРМАХ АЕТСКОГО ЦЕРЕБРААЬНОГО ПАРААИЧА}

\author{
А. П. Фисенко, О. Б. Челпаченко, А. А. Пак, М. О. Волкова, П. А. Зубков, \\ К. В. ЖерАев, У. Ш. Ашрафова, И. В. Киргизов \\ Национальный меАицинский исслеАовательский центр зАоровья Аетей, \\ Москва, Российская ФеАерация
}

\begin{abstract}
This study is based on the results of surgical treatment of 718 patients with musculoskeletal disorders against the background of spastic cerebral palsy. Of these 718 patients, 242 constituted study group 1 (a retrospective study), in which the treatment approach was based on the general principles of orthopedics. Study group 2 comprised 476 children (a prospective study), in which a personalized treatment approach was applied based on the prediction of motor development. The observation period ranged from 6 months to 10 years. Based on a comparative assessment of the Gillette Functional Assessment Questionnaire and data from a gait video analysis, there was an improvement in the results of surgical treatment and a reduction in the length of postoperative rehabilitation in children with musculoskeletal disorders of the lower limbs in spastic forms of cerebral palsy.
\end{abstract}

Keywords: cerebral palsy, personalized approach, treatment, GMFSC, SEMLS

Исследование основано на анализе результатов оперативного лечения 718 пациентов с опорно-двигательными нарушениями на фоне спастических форм ДЦП. Из них 242 пациента составили исследуемую группу 1 (ретроспективное исследование), подход к лечению которых был основан на общих принципах ортопедии. Исследуемую группу 2 составили 476 детей (проспективное исследование), лечение которых было основано на применении персонифицированного подхода на основании прогноза двигательного развития. Период наблюдения составил от 6 месяцев до 10 лет. На основании сравнительной оценки по Gillette FAQ и данных видеоанализа походки отмечалось улучшение результатов оперативного лечения и сокращение продолжительности сроков послеоперационной реабилитации у детей с опорно-двигательными нарушениями нижних конечностей при спастических формах ДЦП.

Ключевые слова: ДЦП, персонифицированный подход, оперативное лечение, GMFSC, SEMLS

For citation: Fisenko A. P., Chelpachenko O. B., Pak L. A., Volkova M. O., Zubkov P. A., Zherdev K. V., Ashrafova U. Sh., Kirgizov I. V. PERSONALIZED APPROACH TO THE TREATMENT OF SUPPORTING MOTOR DISTURBANCES OF THE LOWER EXTREMITIES IN CHILDREN WITH SPASTIC FORMS OF CEREBRAL PALSY. Medical News of the North Caucasus. 2018;13(3):503-507. DOI - https://doi.org/10.14300/mnnc.2018.13090

Для цитирования: Фисенко А. П., Челпаченко О. Б., Пак Л. А., Волкова М. О., Зубков П. А., Жердев К. В., Ашрафова У. Ш., КиргИзОв И. В. ПЕРСОНИФИЦИРОВАННЫЙ ПОДХОД К ЛЕЧЕНИЮ ОПОРНО-ДВИГАТЕЛЬНЫХ НАРУШЕНИЙ НИЖНИХ КОНЕЧНОСТЕЙ ПРИ СПАСТИЧЕСКИХ ФОРМАХ ДЦП. МеДИЦИнСКИЙ веСтнИк Северного Кавказа. 2018;13(3):503-507. DOI - https://doi.org/10.14300/mnnc.2018.13090

$\mathrm{CP} \quad$ - cerebral palsy

Gillette FAQ - Gillette Functional Assessment Questionnaire
GMFCS - Gross Motor Function Classification System SEMLS - Single-Event Multilevel Surgery
Cerebral palsy (CP) is a disease caused by a nonprogressive lesion of the central nervous system in the perinatal period or abnormal development of the brain with gradual formation of secondary orthopedic disorders as the child grows [1]. Despite modern approaches to complex treatment, $\mathrm{CP}$ is still the main cause of pediatric neurological disabilities worldwide [2]. According to epidemiological data, the average incidence of CP is 2.5 per 1000 children [3]. The frequency of CP is higher among premature 
and underweight children, ranging from $1 \%$ to $10 \%$ [4]. Despite the nonprogressive course of the disease, children with $\mathrm{CP}$ require continuous dynamic observation, conservative treatment, and timely orthopedic treatment because of their neurological symptoms and concomitant secondary disorders of the musculoskeletal system (e. g., joint contracture, joint dislocation, bone torsion, and changes in the ligamentous apparatus) in the ontogenesis of motor development $[5,6]$. The following main groups of therapeutic effects have been distinguished by the European Consensus for the treatment of CP: oral antispastic pharmacotherapy, orthopedic surgery, botulinum therapy, intrathecal baclofen, orthotics, and functional therapy (including physiotherapy) [7] Orthopedic surgery is necessary for the treatment of secondary joint contracture and skeletal deformities in patients with $C P$ [8]. With the accumulation of global experience in orthopedic correction of lower extremity musculoskeletal disorders in such patients, a gradual transition of tactics from multistage surgical treatment to so-called simultaneous singlestage multilevel interventions (i.e., single-event multilevel orthopedic surgery) has occurred, allowing treatment to be performed in one surgical session [9]. One of the most difficult problems of surgery for CP is the prompt treatment of spinal deformities. According to the literature, the highest frequency of spinal deformities (up to $70 \%$ ) is observed in patients with the spastic form of CP. Impaired frontal and sagittal balance of the body significantly reduces the stability of the patient's posture and can lead to back pain, which decreases the quality of life among these patients because of a forced decrease in physical activity [10].

Thus, when discussing the main modern approaches to the treatment of $\mathrm{CP}$, we must consider several complex and unresolved issues relating to the radical modernization of tactics, methods of conservative and surgical treatment, and changes in the postsurgical rehabilitation strategy of children with the spastic form of CP.

This study was performed to increase the effectiveness of surgical treatment of children with musculoskeletal disorders of the lower extremities caused by spastic $\mathrm{CP}$ by introducing a personalized approach, taking the prognosis of the patient's motor development into account.

Material and Methods. This study is based on analysis of the results of surgical treatment of 718 patients with musculoskeletal disorders against the background of spastic CP. Surgical treatment was carried out in the neuro-orthopedic department of the FSAU "NMITS of Children's Health» of the Ministry of Health of Russia. Of the 718 patients who underwent surgical treatment, 290 had spastic instability of the hip joints, 147 had contractures or axial deformities of the lower limbs at the level of the knee joints, 245 had neurogenic deformities of the feet, and 36 had deformities of the thoracolumbar spine. Of all 718 patients, 495 (68.94\%) had spastic diplegia, $119(16.57 \%)$ had hemiplegia, and $104(14.49 \%)$ had spastic tetraparesis. The average age of the patients was 7.4 years (range, $2-18$ years).

The development of orthopedic surgery for children with musculoskeletal disorders on the background of CP began with the creation of a traumatology and orthopedic department at the Scientific and Research Institute of Pediatrics of the FSAU «NMITS of Children's Health" of the Ministry of Health of Russia in 2008. The development of this orthopedic surgery center was divided into two stages. In the first stage (2008-2012), the approach to the surgical treatment of this category of patients was based on the general principles of orthopedics. The ideology of this approach to surgical treatment was correction of the severity of the clinical symptoms of the patient's musculoskeletal disorder, the phasing of operational benefits, and conservative treatment if several operations were necessary. At that time, this was dictated by the need to reduce surgical "aggression» in relation to a patient with somatically severe CP. Patients who received surgical care in the first stage constituted study group 1 (a retrospective study). This group comprised 242 children. Data from the patients' medical records (orthopedic and neurological status of the patient as well as data from medical records, outpatient records, and medical reports) were retrospectively analyzed.

Patients with CP-related musculoskeletal disorders who underwent operations in the second stage using a personalized approach based on prediction of the child's motor development comprised study group 2 (a prospective study). This group contained 476 children treated in the neuro-orthopedic department of FSAU «NMITS of Children's Health» of the Ministry of Health of Russia from 2013 to 2018 (after the restructuring of the traumatologic-orthopedic department in 2013). Treatment involved a personalized approach to the surgical correction of neurogenic musculoskeletal disorders based on the prediction of motor development. The main criterion for the prediction of motor development was correct determination of the level of development of large motor functions according to the Gross Motor Function Classification System (GMFCS), which was determined jointly with neurologists during the preoperative examination of the patients. An interdisciplinary approach involving a pediatrician, neurologist, orthopedist, exercise therapy doctor, physiotherapist, speech therapist, pathologist, child psychiatrist, and other specialists provided an individual approach to each child and a weighted decision on the tactics and extent of surgical treatment, taking the comprehensive assessment of the patient's condition into account. By 2013, the components of the complex treatment of children with $\mathrm{CP}$ had already been introduced into the daily work of FSAU «NMITS of Children's Health» of the Ministry of Health of Russia. Surgical treatment of the patients in study group 2 was carried out using simultaneous multilevel interventions.

Clinical, instrumental, radiation, and radiometric research methods were used in the present study. The examination of a child with $\mathrm{CP}$ began by defining his or her global type of movement disorder and muscle tone according to the $10^{\text {th }}$ revision of the International Statistical Classification of Diseases and Related Health Problems. Greater uniformity in the international clinical assessment of patients with $\mathrm{CP}$ was achieved with introduction of a functional classification system of large motor functions (i.e., the GMFCS), developed by Robert Palisano in 1997. According to the GMFCS, there are five levels of development of large motor functions: level I, walking without restrictions; level II, walking with restrictions; level III, walking with the use of manual devices for movement; level IV, self-movement is limited and motorized vehicles can be used; and level V, full dependence of the child on others with transportation in a wheelchair. Comparative standardized analysis of each patient's mobility before and after surgical treatment was assessed dynamically using the Gillette Functional Assessment Questionnaire (Gillette FAQ) 10-point scale [11]. The results were evaluated 6 to 18 months after surgical treatment. 
A gait video analysis was performed for objectification of the quality of walking in patients at levels I to III of the GMFCS, allowing for quantification of changes in the patient's motor stereotype before and after surgical treatment. Forty children with the spastic form of CP after surgical treatment of foot deformities were examined. The unit of video gait analysis was a double step cycle; i.e., the minimum module of a person's walking, limited by the period from the beginning of the foot's contact with the support to the beginning of the next contact of the same foot with the support. Video registration was carried out by means of the two-dimensional hardware-software complex «StarTrace» (Russia) for biomechanical analysis of movements with the conduct and analysis of shooting in two planes (frontal and sagittal). In each frame, the selected kinematic model was built, and the obtained angular and linear kinematics data were analyzed. The average durations of the following rehabilitation periods in each study group were calculated: the postoperative period of plaster immobilization, recovery time to previous (preoperative) physical activity, and time to habilitation to a significant increase in physical activity (for patients who had a significant increase in physical activity on the Gillette scale).

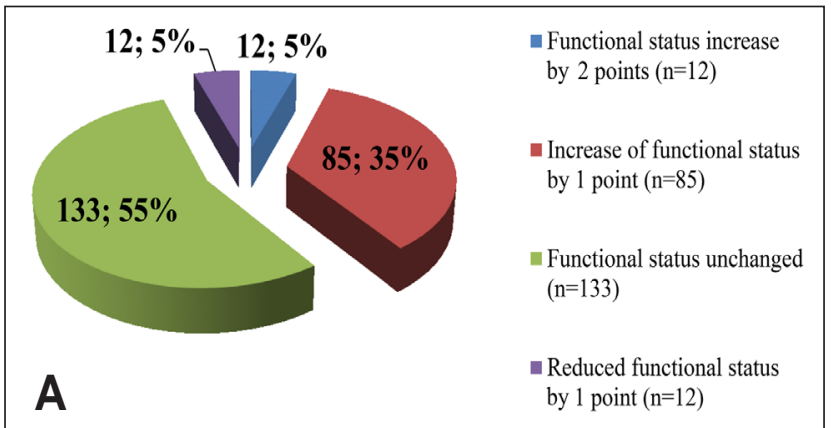

Statistical processing of the data was performed using the Statistica 8.0 statistical analysis package (StatSoft Inc., Tulsa, OK, USA). The data are presented as median, standard deviation, and minimum and maximum values. Differences were considered statistically significant at $\mathrm{p}<0.05$.

Results and Discussion. The functional characteristics of the patients in both groups were compared before and after the surgical treatment according to the Gillette FAQ (Fig. 1). Comparative evaluation of the functional results of surgical treatment according to the Gillette FAQ scale showed an increase in the scores reflecting physical activity in $295(61.97 \%)$ patients in group 2 and in $97(40.08 \%)$ patients in group 1. No dynamics of the functional status for this indicator were present in 171 (35.92\%) patients in group 2 and in 133 (54.96\%) patients in group 1. A decrease in the functional status was found in $10(2.10 \%)$ patients in group 2 and in $12(4.96 \%)$ patients in group 1. Based on the above dynamics of the functional status in the patients in each study group, surgical treatment was significantly more effective in study group 2 than $1(p<0.05)$. Thus, based on the analysis of the functional results, a higher efficacy of surgical treatment was noted in children with CP in group 2.

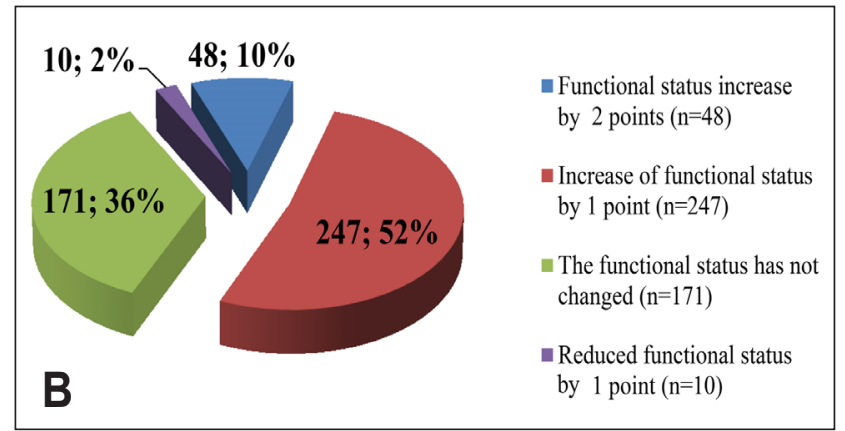

Fig. 1. Comparative analysis of the distribution of study group $1(n=242)$ and study group $2(n=476)$ with respect to the changes in the numbers of points on the Gillette Functional Assessment Questionnaire scale after surgical treatment.

(A) Functional results of treatment of patients in group 1. (B) Functional results of treatment of patients in group 2

We also performed a comparative analysis of the durations of the periods of postoperative rehabilitation after surgical treatment of children with musculoskeletal disorders against the background of CP in each study group. The postoperative period of plaster immobilization in study group 1 was $4.2 \pm 0.8$ months. This period in study group 2 was $1.3 \pm 1.4$ months, which was a significantly better indicator $(p<0.05)$. The recovery time to the previous (preoperative) physical activity level was also significantly different between group 1 ( $4.7 \pm 1.8$ months) and group $2(2.8 \pm 1.1$ months; $p<0.05)$. The time of habilitation to a significant increase in the physical activity level (for patients who had a significant increase in physical activity on the Gillette scale) was $8.9 \pm 2.6$ months in group 1 and $5.9 \pm 2.1$ months in group $2(p<0.05)$. That is, this comparative analysis showed a significant reduction in the duration of rehabilitation of patients whose treatment took into account the prognosis of motor development according to the GMFCS and used simultaneous multilevel surgical interventions.

In the gait video analysis, assessment of the linear kinematics of the common center of gravity in the frontal plane made it possible to determine that by the end of the course of rehabilitation treatment in 25 patients who had undergone surgical correction of foot deformities, the variability decreased (the ratio of the points of deviation from the axis during the walking cycle before treatment was $2: 1$, and that after treat- ment was $1: 1$ ) and the speed of movement decreased (Fig. 2). These results indicate an increase in the stability of the patient's vertical axis. A significant improvement in the cinematogram of the ankle joints was noted $(p<0.05)$. We also observed a significant increase in the coefficients of variation of walking at the maximum point in the posterior impulse phase and in the period of foot transfer with the minimum angle in the ankle joint (the average coefficient of variation at selected points on the cinematogram before surgical treatment was $4.81 \pm 1.38$, and that after surgical treatment was $4.61 \pm 1.40)(p<0.05)$. All changes were regarded as a positive effect of surgical treatment and comprehensive rehabilitation against the background of changes in the subjective examination data.

When choosing the optimal age for surgical correction of musculoskeletal disorders of the lower limbs of the patients in group 2, we used the recommendations of the European Consensus for the treatment of children with $C P[12,13]$. In determining the indications for orthopedic surgery, we avoided surgical aids until the age at which children at each specific level of the GMFCS reached, on average, $90 \%$ of their potential motor development. For patients at levels I, II, III/IV, and $\mathrm{V}$ on the GMFCS, this age is $5.0,4.5,3.5$, and 3.0 years, respectively. After patients with $\mathrm{CP}$ attain these ages, the severity of neurological disorders does not change at later ages $[14,15]$. 

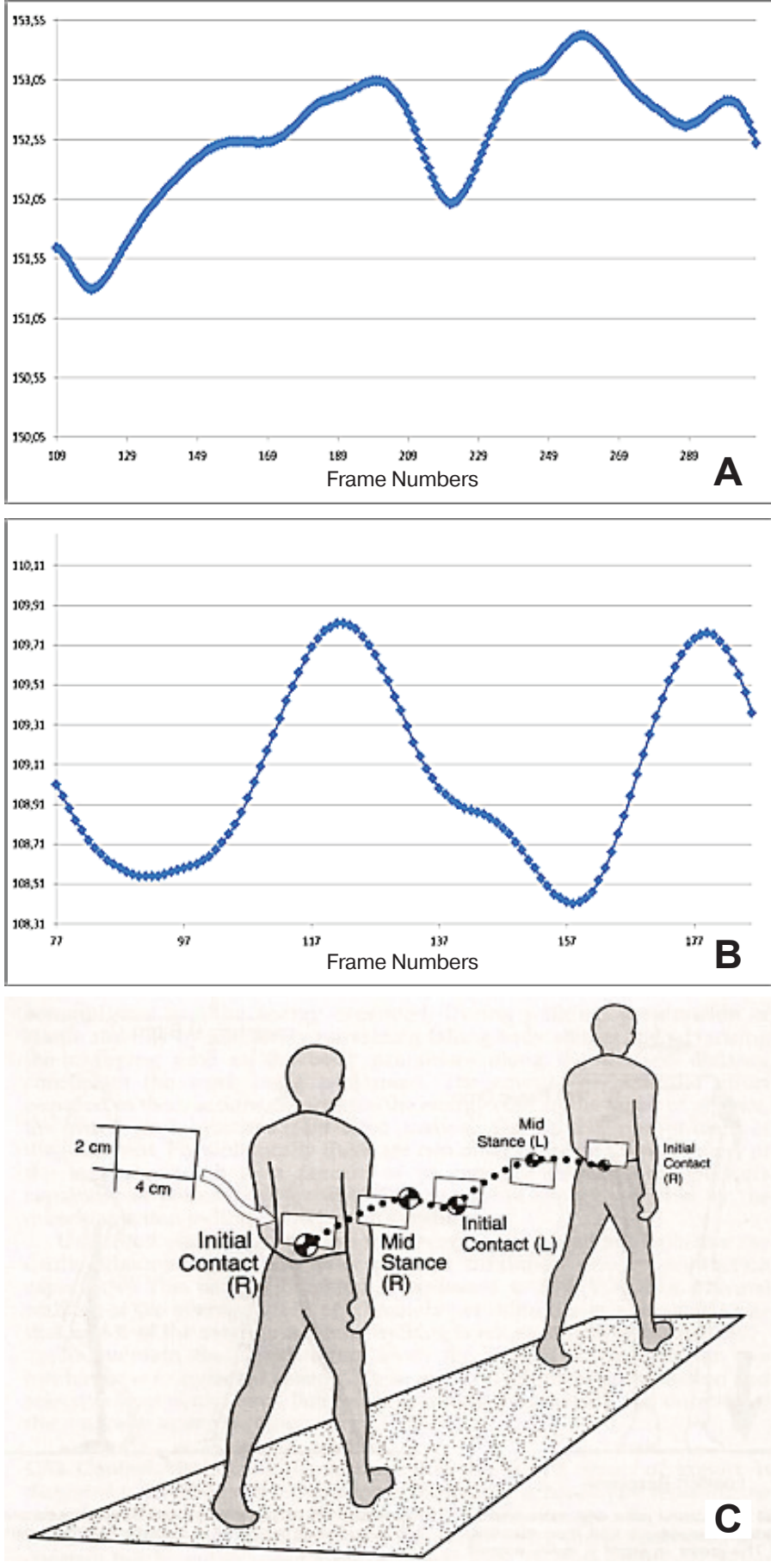

Fig. 2. Results of the video analysis of the patient's gait after surgical treatment of foot deformity. (A) Cinematogram of the patient before surgical treatment (correction of equinus of the right foot).

(B) Cinematogram of the patient 6 months after surgical treatment and rehabilitation. (C) Schematic representation of the movement of the center of gravity of the patient's body in the sagittal plane while walking (Perry J., 1992)
Analysis of the level of formation of large motor functions allows us to compare the dynamics of motor development of a patient with CP not with the age norm, but with the average rate of development of children with a similar level of motor deficit; that is, in comparison with the «natural course of the disease.» Patients at levels I and II of the GMFCS have a high habilitation potential and accordingly have the ability to move vertically without using additional means of support. Notably, the progression of lower limb musculoskeletal disorders may significantly limit this ability in the future. Patients at level III on the GMFCS are the most «sensitive» to the choice of treatment tactics. To a large extent, the choice of treatment tactics depends on the initial degree of the patient's motor activity because such patients move either with the help of additional means of support or with the help of a wheelchair in a sitting position. Musculoskeletal disorders of the lower extremities significantly reduce the patient's tolerance to walking and the quality of the gait. With the progression of pathological dysfunction of the lower extremities, these patients often lose the ability to move independently. The purpose of orthopedic operating aids for patients at level IV on the GMFCS is to recreate a stable sitting position, in which such patients spend most of their lives. Secondary spinal deformities, pelvic distortion, instability of the hip joints, and secondary pathological dysfunction of the lower extremities prevent these patients from maintaining a stable sitting position. This reduces their social adaptation because of the unstable position of the body and limbs in space. Patients at level $\mathrm{V}$ of the GMFCS can maintain half-sitting and reclining positions, but secondary orthopedic disorders due to muscle spasticity make it difficult to transport these patients and care for them daily.

Conclusions. Themaincriterionfortheeffectiveness of treatment is the patient's acquisition of a more stable posture and the ability to move in comparison with the natural course of the disease. The choice of tactics in the surgical treatment of patients with $\mathrm{CP}$ is dictated by the level of formation of large motor functions (i.e., the GMFCS level), which allows for accurate determination of the prognosis of the child's motor development. Our comparative assessment of the patients' motor activity before and after surgical treatment according to the Gillette FAQ scale showed that the use of an integrated personalized approach to surgical correction of lower limb musculoskeletal disorders based on the prediction of motor development significantly increased the treatment effectiveness for children with spastic CP. This was also confirmed by the comparative gait video analysis. The introduction of single-event multilevel orthopedic surgery contributed to a reduction in the durations of postoperative plaster immobilization and postoperative rehabilitation, thus helping to prevent loss of the skills that the child has already attained. The effectiveness of an interdisciplinary team of specialists suggests that a personalized approach based on prediction of the motor development of children with $\mathrm{CP}$ should be considered the gold standard of high-quality treatment for children with $\mathrm{CP}$.

Disclosure:

The authors declare no conflict of interest.

Acknowledgment. We thank Angela Morben, DVM, ELS, from Edanz Group, (www.edanzediting.com/ac) for editing a draft of this manuscript.

References

1. Graham H. K., Rosenbaum P., Paneth N., Dan B., Lin J. P. [et al.] Cerebral palsy. Nat. Rev. Dis. Primers. 2016;2:15082. https://doi.org/10.1038/nrdp.2015.82
2. Elani S., Miller J. E., Chunsen W., Bech B. H., Pedersen L. H. [et al.] Disproportionate Fetal Growth and the Risk for Congenital Cerebral Palsy in Sin- 
gleton Births. PLOS ONE. 2015;10(5):e0126743. https://doi.org/10.1371/journal.pone.0126743

3. Zherdev K. V., Pak L. A., Volkova M. O., Zubkov P. A., Chelpachenko O. B. Aktualnye napravleniya optimizatsii khirurgicheskogo lecheniya oporno-dvigatelnykh narusheny pri spasticheskikh formakh detskogo tserebralnogo paralicha. Rossysky pediatrichesky zhurnal. 2018;21(3):175-181.

4. Rogoveanu O Tutescu N Kamal D. Alexandru D. Kamal C. [et al.] Correlations between risk factors and functional evolution in patients with spastic quadriplegia. Journal of Medicine and Life. 2016;9(2):170-176.

5. Malakhov O. A., Zherdev K. V., Trankovsky S. E., Malakhov O. O. Differentsialny podkhod k khirurgicheskoy korrektsii patologii tazobedrennykh sustavov u detey s DTsP. Detskaya khirurgiya. 2014;18(3):4-8

6. Hägglund G., Alriksson-Schmidt A., Lauge-Pedersen H., Rodby-Bousquet E., Wagner P. [et al.] Prevention of dislocation of the hip in children with cerebral palsy: 20-year results of a population-based prevention programme. Bone Joint J. 2014;96-B(11):1546-1552.

7. Büyükavcı R., Büyükavcı M. A. Effects of ultrasound-guided botulinum toxin type-A injections with a specific approach in spastic cerebral palsy. Acta Neurologica Belgica. 2018;118(3):429-433. https://doi.org/10.1007/s13760-018-0929-5

8. Sharan D. Orthopedic surgery in cerebral palsy: Instructional course lecture. Indian J. Orthop. 2017;51(3):240255. https://doi.org/10.4103/ortho.IJOrtho 19716

9. Lamberts R. P., Burger M., du Toit J., Langerak N. G. A Systematic Review of the Effects of Single-Event Mul- tilevel Surgery on Gait Parameters in Children with Spastic Cerebral Palsy. PLOS ONE. 2016;11(10):e0164686. https://doi.org/10.1371/journal.pone.0164686

10. Baklanov A. N., Kolesov S. V., Shavyrin I. A. Operativnoye lecheniye deformatsy pozvonochnika u patsiyentov s detskim tserebralnym paralichom. Travmatologiya $i$ ortopediya Rossii. 2011;61(3):73-79.

11. Aranovich A. M. Popkov A. V Shchukin A. A Medvedeva S. N., Yevreinov V. V. [et al.] Rezultaty mnogourovnevykh odnomomentnykh operativnykh vmeshatelstv u patsiyentov s detskim tserebralnym paralichom. Geny ortopedii. 2013;(4):53-60.

12. Klinicheskiye rekomendatsii MZ RF «Detsky tserebralny paralich». 2016;34.

13. Heinen F., Desloovere K., Schroeder A. S., Berweck St., Borggraefe I. [et al.] The updated European Consensus 2009 on the use of Botulinum toxin for children with cerebral palsy. Eur. J. Paediatr. Neurol. 2010;14:45-66. https://doi.org/10.1016/i.ejpn.2009.09.005

14. Baranov A. A., Namazova-Baranova L. S., Kurenkov A. L., Klochkova O. A., Mamedyarov A. M. [et al.] Kompleksnaya otsenka dvigatelnykh funktsy u patsiyentov s detskim tserebralnym paralichom: ucheb.-metod. Posobiye. M.: Pediatr, 2014:84.

15. Wright F. V., Rosenbaum P., Fehlings D., Mesterman R. Breuer U. [et al.] The Quality Function Measure: reliability and discriminant validity of a new measure of quality of gross motor movement in ambulatory children with cerebral palsy. Dev. Med. Child. Neurol. 2014;56(8):770-778. https://doi.org/10.1111/dmcn.12453

\title{
About authors:
}

Fisenko Andrey Petrovich, MD, PhD, Professor, Director; e-mail: fisenko@nczd.ru

Chelpachenko Oleg Borisovich, MD, PhD, Traumatologist-orthopedist, leading researcher of the Laboratory of Neurology and Cognitive Health; tel.: +74991340786; e-mail: chelpachenko81@mail.ru

Pak Lale Alievna, MD, PhD, Leading researcher of the Laboratory of Rare Hereditary Metabolic Children Diseases; e-mail: Iolitap@mail.ru Volkova Maria Olegovna, PhD student; tel.: +74991340786; e-mail: ortopediya@gmail.com

Zubkov Pavel Andreevich, PhD student; e-mail: ortopediya@gmail.com

Zherdev Konstantin Vladimirovich, MD, PhD, Head of the Department of Neuroortopedics and Ortopaedics; tel.: +74991340786; e-mail: drzherdev@mail.ru

Ashrafova Ulviya Shakenovna, MD, Neurologist at the Department of Diagnostic and Rehabilitation Medicine of Children with Psychoneurological Pathology; tel.: +74991340169; e-mail: ashrafova@nczd.ru

Kirgizov Igor Vitalevich, MD, PhD, Professor, Head of the Pediatric Surgery Unit; tel.: +79057720953; e-mail: drkirgizov@yandex.ru

(C) Group of authors, 2018

UDC 581.616.192

DOI - https://doi.org/10.14300/mnnc.2018.13091

ISSN - 2073-8137

\section{ANTIOXIDANT AND HEMOLYTIC PROPERTIES OF DIFFERENT EXTRACTS FROM PRUNELLA VULGARIS L. LEAVES}

Ohanyan A. Dj. ${ }^{1}$, Shishkoyan N. J. ${ }^{1}$, Kazaryan Sh. A. ${ }^{1}$, Hovhannisyan A. A. ${ }^{1}$, Tiratsuyan S. G. 1, Elbekyan K. S. ${ }^{2}$, Koshel V. I. ${ }^{2}$, Khodzhayan A. B. ${ }^{2}$

${ }^{1}$ Russian-Armenian University, Yerevan, Republic of Armenia

2 Stavropol State Medical University, Russian Federation

\section{АНТИОКСИААНТНЫЕ И ГЕМОАИТИЧЕСКИЕ СВОЙСТВА

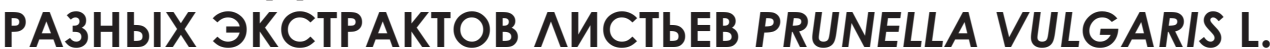

\author{
А. Ж. Оганян ${ }^{1}$, Н. Аж. Шишкоян ${ }^{1}$ \\ С. Г. Тирацуян ${ }^{1}$, К. С. Э^ьбекян ${ }^{2}$, В. \\ Ш. А. Казарян ${ }^{1}$, А. А. Оганесян ${ }^{1}$, \\ 1 Российско-Армянский университет, Ереван, Республика Армения \\ 2 Ставропольский госуАарственный меАицинский университет, Российская ФеАерация
}

The plant Prunella vulgaris L. has long been used in traditional European and Asian medicine. Its extracts revea immunoprotective, antitumor, antiinflammatory, and antiestrogenic features. We obtained aqueous and ethanol extracts from $P$. vulgaris L. leaves; carried out HPLC analysis; detected the total flavonoids content and the antiradical activity. The 